\title{
Analysis on the Difficulties in the Development of Rural Tourism Against the Background of Poverty Alleviation and Its Path
}

\author{
$\mathrm{Na}$ Han \\ School of Economic and Management \\ Zaozhuang University \\ Zaozhuang, China 277100
}

\author{
Tiantian $\mathrm{Gu}^{*}$ \\ School of Economic and Management \\ Zaozhuang University \\ Zaozhuang, China 277100 \\ *Corresponding Author
}

\begin{abstract}
At present, poverty alleviation work in China has entered a crucial period and rural tourism is a new path and an important measure to help the poor in the new era under the general background. This paper first introduces the development history of rural tourism at home and abroad and related theories. Through the comparison of rural tourism development models at home and abroad, this paper analyzes the main dilemmas of rural tourism development, discusses the operational mechanism of rural tourism, and finally proposes the appropriate path for rural tourism development in China.
\end{abstract}

Keywords-poverty alleviation; rural tourism; Internet; smart tourism

\section{INTRODUCTION}

A few days ago, the National Tourism Administration and the State Council Poverty Alleviation Office issued the "Action Plan for Supporting Poverty Alleviation in Deep Poverty Areas" (hereinafter referred to as the "Plan"), and pointed out that it will focus on deep poverty-stricken areas and effectively increase tourism support for poverty alleviation. The program stated that the goal of poverty alleviation in poverty-stricken areas is that by 2020 , the level of tourism poverty alleviation planning in poverty-stricken areas such as "three districts and three states" will be significantly improved, infrastructure and public service facilities will be significantly improved, rural tourism poverty alleviation measures will be more powerful, the quality of rural tourism poverty alleviation personnel will be improved significantly, the quality of featured tourism products will be improved significantly, rural tourism brands can be effectively promoted, tourism comprehensive benefits will be continued to grow, tourism poverty alleviation results are continuously consolidated, and rural tourism plays an effective role in driving and promoting the poverty alleviation in poverty-stricken areas such as "three districts and three states".

In recent years, as one of the industries with the highest degree of marketization in China, tourism has gradually become a pillar industry of the national economy. As a branch of tourism, rural tourism shows the vigorous vitality exceeding general industry because it integrates the three industries, connects urban and rural areas and is more rich in "homesickness", which adapts to the unique advantages of the growing short-distance leisure and holiday consumption needs of urban residents and plays an increasingly important role in improving the quality of life of urban and rural residents, promoting sustained economic and social development, and promoting poverty alleviation in povertystricken areas.

\section{TYPICAL CASE OF RURAL TOURISM AGAINST THE BACKGROUND OF POVERTY ALLEVIATION}

\section{A. Sichuan Province}

In recent years, the achievements of tourism poverty alleviation in Sichuan have been remarkable. In 2016, through the implementation of rural tourism poverty alleviation projects, the province's total rural tourism revenue reached 2015 billion yuan, an increase of 22\%. There are 2,291 new rural tourism cooperatives, which promote 448 poverty-stricken villages to achieve poverty alleviation through the development of rural tourism. Nine povertystricken counties were established as provincial-level tourism poverty alleviation demonstration zones, driving 835,600 poor people to directly benefit or indirectly benefit. The per capita net income of farmers' households engaged in tourism reached 1,5322.9 yuan, a year-on-year increase of $13.5 \%$.

In 2017, Sichuan Tourism Development Committee proposed three major tourism poverty alleviation strategies, including characteristic format support, industrial integration development and tourism marketing, to promote the transformation of tourism resources advantages into industrial advantages in poverty-stricken areas, and to effectively make rural tourism an industry that can increase income and reduce poverty.

Under the guidance of the three major tourism poverty alleviation strategies, in 2017 , the province promoted the construction of 364 national poverty alleviation key villages of rural tourism. They implemented tourism poverty alleviation demonstration project, and supported six poverty- 
stricken counties such as Jiuzhaigou County and Lixian County to establish provincial-level tourism poverty alleviation demonstration zones through financial support and standardization construction, to radiate and drive peripheral development. They also created 112 provinciallevel tourism poverty alleviation demonstration villages, implemented the "Ten Thousand Villages and Ten Thousand Households" tourism enrichment plan, and form an interest linkage mechanism for tourism development and poverty alleviation.

Floating Cloud Ranch is a microcosm of Sichuan's implementing strategy of tourism poverty alleviation and support of characteristic industry. In the Tibetan Plateau in Sichuan, in order to promote the quality and efficiency of rural tourism, Sichuan Province has effectively solved the problem of the harmonious development of original ecological culture and natural ecological environment protection and tourism development through the creation of boutique property and other characteristic industries, which effectively avoid the destruction of the original ecological culture of the village by the influx of tourists.

In recent years, the role of the Sichuan Provincial Rural Cultural Tourism Festival has become more and more obvious. It is not only an important activity for the development of rural tourism in the province "promoting construction through committee and promoting sales through committee", but also the important grip for Sichuan Tourism Development Committee to "establish a boutique and support new products". Since 2015, Sichuan Provincial Rural Cultural Tourism Festival has been transformed from once a year to four times one year. Rural tourism is an important catcher of precision poverty alleviation in Sichuan. The "Four Seasons" rural tourism festival has given show stage to the beautiful countryside of our province. This stage allows beautiful villages to get in touch with tourists and better connect with the market. In addition to the opening ceremony, the series of activities of the Rural Tourism Festival will last for several months to expand the influence of the festival marketing.

\section{B. Jiulong Township}

"Jiulong Township" is located in the core area of Yingxi Fenglin, Jiulong Town, Qingyuan City, Guangdong Province. It involves 6 administrative villages including Hetou, and is one of the key projects of Jiulong Town to create characteristic towns and famous tourist towns. The project covers an area of about 7,000 mu, and develops the "eight major industries": agricultural parks, country hotels, characteristic B \& B, flower enjoying, leisure sightseeing, health and vacation, science education, and outdoor development with a total investment of 300 million yuan. The first phase was completed and opened in July, 2016. Driven by the "Jiulong Township", Hetou Village, where the core area is located, was awarded the title of "National Top 100 Beautiful and Livable Demonstration Village". In August 2017, CCTV's "Green China" column made a special report entitled "The Transformation of Tianyan Mountain, the Back Garden of the Neighboring City".
The township adopts the model of "enterprise + village economic society + farmers", and has created a "new three changes" development model of "resources changing to asset, asset changing to stock right, and farmers changing to tourism participators". Resources changing to asset means that village collectives revitalize resources such as swamps, stone mountains, abandoned wasteland, and old mud brick houses that have no economic value before, and make united new plan to create attractions and B \& B etc., and turn "dead resources" into "live asset." Assets changing to stock right means that villagers become shareholders of village collective with land, and then the village collective (village economic cooperative) participate in the "Jiulong Township" tourism project with land. The villagers share fixed dividends every year. Farmer changing to tourism participator means that villagers take up an occupation nearby and provide tourism supporting services. At present, more than 320 local villagers have joined the national industry company as planting staff, security personnel and management personnel in the scenic spot. Some villagers run parking lots in the scenic spot, sell local products, and radiate the surrounding villagers to build their own B\&B and agritainment.

Poor households sign a shareholding agreement with the enterprise as a unit of the village economic cooperative, and all kinds of poverty alleviation funds are invested in the enterprise, so the poor households share $10 \%$ of the proceeds of the share capital every year. It is estimated that by the end of 2018, the annual income of poor households will reach over 8,000 yuan per person, and the poverty alleviation will be fully realized. In addition, led by the Provincial Party Committee Office of Hetou Village, National Industry Tourism Company and Rainbow Fund jointly established the "Rainbow National Industry Poverty Alleviation Fund" to directly assist local poor students. Since its establishment, the fund has subsidized more than 30,000 yuan for 115 poor students in the town.

\section{THE MAIN DILEMMA OF RURAL TOURISM DEVELOPMENT IN CHINA AGAINST THE BACKGROUND OF POVERTY ALLEVIATION}

\section{A. The Funding Bottleneck Problem is Highlighted}

Most of the rural poor live in remote mountainous areas. Although these mountainous areas have rich tourism resources, due to the special natural environment, the development of tourism projects is difficult and requires large capital investment.

\section{B. Rural Hollowness Is Serious, Which Is Not Conducive to the Implementation of Tourism Poverty Alleviation Projects}

At present, most of the young and middle-aged in rural areas are working outside, and the elderly and children are left at home. This phenomenon is mainly caused by the "thrust" of the rural areas and the "pull" of the surrounding cities, which means that the attractiveness of agricultural employment is not strong, while the rural areas lack supportive secondary and tertiary industries, resulting in 
surplus rural labor, so rural surplus labors are forced to go out to work. The surrounded provinces Zhejiang, Guangdong, and Fujian with developed economy and employment opportunities attract a large number of rural labors. Therefore, the large-scale rural surplus labor move to developed cities, which causes rural hollowing out and adversely affected the implementation of tourism poverty alleviation projects.

\section{The Awareness of Poverty Alleviation of Poor Population Is Not Clear}

The purpose of accurate poverty alleviation in rural tourism is to improve the living conditions of the poor. In the rural poor population, the ideological concept of sticking to convention is still the mainstream. The poor people involved in the development of tourism are scattered, and some even give up, so the effect of poverty alleviation is not obvious.

\section{There Are Obstacles in E-commerce Precision Poverty Alleviation}

In November 2016, the State Council issued the "Guiding Opinions on Promoting Accurate Poverty Alleviation through E-commerce", which pointed out that the development of rural e-commerce in poverty-stricken areas is still in its infancy, so the construction of e-commerce infrastructure is underdeveloped without overall guidance. The scarce e-commerce talents, low degree of marketization, lack of standardized products, and poor online trading capacity of poor people have affected the pace of rural poor people's employment, entrepreneurship and poverty alleviation through e-commerce.

\section{SUGGESTIONS ON THE PATH OF RURAL TOURISM DEVELOPMENT IN CHINA AGAINST THE BACKGROUND OF POVERTY ALLEVIATION}

\section{A. Leadership of Government and Guidance of Policy}

First, the government should carry out scientific planning for villages and formulate rural tourism poverty alleviation development plans and related policies. Second, they can support and guide poor farmers to participate in the development and management of rural tourism through support policies and financial support; finally, they should strengthen and improve rural tourism infrastructure construction, and focus on road construction, environmental improvement, greening construction, public service system construction and tourism infrastructure.

\section{B. Integrating Resources and Using Internet Thinking to Innovate Products and Services}

At present, rural tourism is in the stage of perfection, and the shape of tourist destinations is still relatively primitive. Most of them still remain in the eating country style food, picking vegetables and fruits, making barbecue or angling, and watching the crops, mountains and field. With the advent of the "Internet + " era, rural tourism has ushered in a new driving force, and it is necessary to re-examine and think about the market, products, services and business methods of rural tourism. This requires the consciousness of innovation and differentiation. They need to learn to use the Internet and other internal and external information to analyze the aspirations of tourists, find product ideas, and create a "network style" for rural tourism. The "Internet +" era requires innovative and intelligent tourism products that can highlight the characteristics of rural tourism resources and contain diverse and individualized cultural connotations.

\section{Stereoscopic Marketing to Enhance the Brand}

Make full use of the new media to promote and popularize the natural rural landscape, unique folk customs, wonderful folklore, local products and so on in rural tourism through the official website of rural tourism, mobile portal or cooperation with Sina, Tencent, and Netease, etc. to enhance and promote the online service function of rural tourism. Using the new media tools such as WeChat, Michao, and Tik Tok for comprehensive marketing, we can also cooperate with virtual tourism companies to display rural tourism features through virtual 3D software to enhance the perception of visitors.

\section{Focusing on Manpower and Building Training Mechanisms}

The target population for rural tourism poverty alleviation and development is those poor people who have the ability to work and the willingness to participate in the development of rural tourism and can be supported by tourism development. However, these people usually have limited knowledge and weak participation ability, which restricts the depth of the participation of poor people in rural tourism development, so equal distribution of benefits can't be obtained.

\section{CONCLUSION}

This paper analyzes the main dilemmas of China's rural tourism development model under the background of poverty alleviation mainly through introducing the typical rural tourism development cases in Sichuan Province and Jiulong Township. The dilemmas include bottleneck of funds, the serious hollowing out of rural areas, the unclear awareness of poverty-stricken people, and obstacles in the e-commerce targeted poverty alleviation. Combining the successful cases of Sichuan Province and Jiulong Township, the main suggestions for rural tourism development in China include government leading and policy guiding; integrating resources and using Internet thinking to innovate products and services; stereoscopic marketing to enhance brands; and focusing on manpower and building training mechanisms . Although this paper draws recommendations for the development of rural tourism, there are still some shortcomings. In the future, the main research directions should focus on the comparison of typical cases at home and abroad, and get more specific and practical operating mechanism of rural tourism development through the specific field research and data analysis. 


\section{REFERENCES}

[1] Ashley C, Boyd C, Goodwin H. Propoor tourism: putting poverty at the heart of the tourism agenda [J]. ODI Natural Resource Perspectives, 2000, 51(6) .

[2] Deng J, Bauer T, Huang Y. Ecotourism, protected areas, and globalization: issues and prospects in China[J]. ASEAN Journal on Hospitality and Tourism, 2003, 2(1) : 17- 32

[3] Goodwin H. Pro Poor Tourism Opportunities for Sustainable Local Development [J]. D+ C Development and Cooperation , 2000, (5) : 12- 14.

[4] Jim C Y, Xu S S W. Stifled stakeholders and subdued participation: Interpreting local responses toward Shimentai Nature Reserve in South China[J] . Environmental Management, 2002, 30( 3) : 327- 341.

[5] Oakes T. Tourism and modernity in China [M]. London UKRoutledge, 1998.

[6] Sofield T H B, Bauer J, De Lacy, T, Lipman G, Daugherty S.Sustainable tourismeliminating poverty (STEP): An Overview [M] ,World Tourism Organization (WTO). 2004.

[7] Stone M, Wall G. Ecotourism and community development: Casestudies from Hainan, China [J] . Environmental Management, 2004, 33( 1) : 12- 24.

[8] Swain M B A comparison of state and private artisan production fortourism in Yunnan [A] . Tourism in China : geographic, political, and economic perspectives [C] . Boulder Colorado USA, Westview Press Inc. , 1995: 223- 233.

[9] Toops S W. The tourism and handicraft industries in Xinjiang:development and ethnicity in a minority periphery $[\mathrm{J}]$. Humanities and Social Sciences, 1991, 51(9) : 31- 81.

[10] Walsh E R, Swain M B Creating modernity by touring paradise:domestic ethnic tourism in Yunnan, China, $[\mathrm{J}]$. Tourism Recreation Research , 2004, 29(2) : 59- 68.

[11] Xiao $\mathrm{H}$ and $\mathrm{Li} \mathrm{L}$. Villagers perceptions of traditions: someobservations on the development of rural cultural tourism in China [ J] . Tourism Recreation Research, 2004, 29(2) : 69- 80.

[12] Xu G and Kruse C. Economic impact of tourism in China[Z] . Lew AA, Yu L, Ap J, Guangrui Z. Tourism in China[C] . Binghamton, USA, Haworth Hospitality Press. 2002, : 83- 101.

[13] Zhang H Q, Chong K, Ap J. An analysis of tourism policydevelopment in modern China[J] . Tourism Management, 1999, 20 ( 4) : 471- 485.

[14] Bai Fengzheng, Li Jiangsheng. Research on Management Model of Tourism Poverty Alleviation Experimental Area [J]. On Economic problems, 2002, ( 9) : 23- 25.

[15] Cao Jianhua. Research on the impact of tourism on rural areas and farmers in China [D]. Graduate School of Chinese Academy of Social Sciences, 2002.

[16] Cao Xinxiang, Ding Shengyan. Behavior of the government in tourism poverty alleviation and development [J]. Journal of Xuchang University, 2003, 22( 2) : 60- 64.

[17] Cao Yanying, Wei Jianguo, Wei Xinhua. Advantages, problems and countermeasures of developing sightseeing agriculture and rural folklore tourism in Yantai City [J]. Yantai Teachers University journal(Natural Science Edition), 2004, 20(3) : 223- 228.

[18] Chen Xiuqiong, Huang Jinhuo. A Brief Discussion on Community Participation in Ecotourism Development [J]. Journal of Huaqiao University(Humanities \& Social Science), 2003, (3) : 38- 42.

[19] Cheng Zhanhong. A study on the behavioral characteristics of people engaged in tourism industry in ecotourism communities : Taking Luyashan Nature Reserve as an example [J] Journal of Shanxi University ( Natural Science Edition), 2001, 24( 2) : 159- 163.

[20] Ding Huanfeng. A Review on the Research of Domestic Tourism Poverty Alleviation [J] . Tourism Tribune, 2004, 19(3) : 32- 36.

[21] Fan Chun. Development of Rural Tourism [J]. Journal of Yuzhou University (Social Science Edition), 2002, (5) .

[22] Guo Qingxia. Problems and countermeasures in tourism poverty alleviation and development [J]. Economic Geography, 2003a, 23(4): 558-560.
[23] Guo Qingxia. Tourism Poverty Alleviation PPT Strategy and Its Characteristics — Taking Hubei Province as an Example [J]. Journal of Hubei University(Philosophy and Social Sciences), 2003b, (5): 110-113.

[24] Han Lin. Exploration on the Construction of Yangshuo Rural Tourism Network [J]. Journal of Guilin Institute of Tourism, 2004, 15(6) : 82- 86.

[25] Han Lin. On the promotion role of the Internet to the development of rural tourism [J]. Journal of Guilin Institute of Tourism, 2003, 14( 2): 75- 80 . 